\title{
Basic characteristics of small and medium-sized enterprises in terms of their strategic management.
}

\author{
Monika Březinová \\ Faculty of Economics \\ JCU \\ České Budějovice, Czech Republic \\ brezina ef.jcu.cz
}

\begin{abstract}
The strategic management represents current direction of management. It is applied in all types of enterprises, including small and medium sized ones. Using principles of process management within SMEs has its limitations caused mainly by the size of the enterprise and the related focus on operational management. Other specifics are function accumulation, informal leadership, preference of oral communication to written, etc. Nevertheless, implementation of strategic management can increase competitiveness, reduce costs, improve decision-making, facilitate implementation of the employee motivation system, shorten delivery times, raise quality of customer satisfaction, etc. The aim of this article is to find out how to what extent SMEs implement the principles of strategic management.
\end{abstract}

Keywords-strategic management; SMEs; strategy; quality and stabilization (key words)

\section{INTRODUCTION}

SMEs are indispensable in all economies, can be described as a driving force of business, growth, innovation, competitiveness, and are also very important employers. In the Czech Republic 1066787 legal and natural persons who are placed in the category of small and medium-sized enterprises. Performed some business activity until 31th December 2011. From total number of active enterprises small and mediumsized enterprises created $99.84 \%$ in 2011. Percentage of employees in small and medium-sized enterprises amounted to $60.85 \%$ in relation to the employees of the Czech economy. According to Řehor [1], in 2007 the small and medium-sized businesses will create and offer new and quality jobs.

According to Srpová [2], management of small and medium-sized enterprises has many specifics. In small companies, due to the small number of employees and managers, many functions are accumulated within the competence of only a few workers, informal leadership is more common, oral communication is preferred to written, etc. According to the team of authors [3] however, a high degree of flexibility to adapt rapidly to changing SME factors determines the ability to face and reduce the growing globalization tendencies associated with the onset of multinational corporations and chains.
Strategic management, based on long-term forecasts, helps the company to anticipate future challenges and opportunities [4]. According Sedláčková, Buchty [5]strategic management gives clear goals and directions for the future of the company and its workers a sense of security. Strategic management helps to increase the quality of management, leads managers to improve their decision making. Keřkovský, Vykypěl further say that strategic management helps improve communication in the company, project coordination, staff motivation and resource allocation.

Dedouchová [6] gives two definitions of strategy, traditional and modern. Traditional definition explains the strategy of the company as a document in which there are long-term objectives of the company, determined processes of operations and allocations of the resources needed to meet these goals. The modern concept sees the strategy as the company prepared for the future. The strategy includes the long-term objectives of the company, the process of strategic operations and deployment of company resources needed to meet these goals. It means the strategies are based on business needs, take into account the changes of their resources and capabilities, and at the same time adequately respond to the changes in the environment of the company. The central concept of strategic management is a strategy that is closely linked to the objectives it tracks. According to Kotler, Keller, [7] strategies express the basic idea of how to achieve the company goals.

The article deals with the mapping of the fundamental characteristics of SMEs in terms of their strategic management.

\section{RESEARCH METHODOLOGY}

This article represent one of the outputs of the research project "Process management and the possibility of its implementation in small and medium-sized enterprises of the " Grant Agency of the University of South Bohemia GAJU 068/2010/S and serves as one of the sources for grant GAJU $039 / 2013 /$ S. The research project used secondary figures (financial statements of the surveyed SMEs) and primary figures which were obtained primarily through quantitative methods questionnaire supplemented by qualitative method of 
in-depth interviews. For the classification of small and medium-sized enterprises a new definition of the European Union was used (European Commission: A new definition of SMEs 2006) in accordance with the Law No. 47/2002 Coll., amended. This system was adapted for the needs of the research, the following „Tab.1”, where the group of small businesses was divided into two groups according to the number of employees in order to achieve detailed characterization.

TABLE I: Classification of SMEs.

\begin{tabular}{|l|c|l|c|}
\hline $\begin{array}{l}\text { Enterprise } \\
\text { size }\end{array}$ & $\begin{array}{c}\text { Number of } \\
\text { employees }\end{array}$ & \multicolumn{1}{|c|}{ Annual turnover } & $\begin{array}{c}\text { annual } \\
\text { balance sheet }\end{array}$ \\
\hline $\begin{array}{l}\text { Medium } \\
\text { enterprise }\end{array}$ & $50-249$ & $<50$ mil. $€$ & $<50$ mil. $€$ \\
\hline $\begin{array}{l}\text { Small } \\
\text { enterprise }\end{array}$ & $25-49$ & $<10$ mil. $€$ & $<10$ mil. $€$ \\
\hline & $10-24$ & $<10$ mil. $€$ & $<10$ mil. $€$ \\
\hline $\begin{array}{l}\text { Micro } \\
\text { enterprise }\end{array}$ & $0-9$ & $<2$ mil. $€$ & $<2$ mil. $€$ \\
\hline
\end{tabular}

In the South Bohemian region, in 2011, 68,826 economic entities from the selected category were registered.

Enterprises with up to 9 employees (micro-enterprises) represent $18 \%$ of the total number. Small enterprises represent less than $4 \%$ of all the small and medium-sized enterprises in the region.

There are registered $78 \%$ of medium-sized enterprises within the region (Statistický bulletin - Jihočeský kraj 2011, Statistical bulletin).

According to the legal form of business in the basic aggregate private entrepreneurs (77\%) there dominate then companies (9\%), associations (5\%), corporations of proprietors and cooperatives (3\%), foreign persons (2,5\%) and others. (European Commission. Key figures on European business with a special feature on SMEs 2011).

The prevailing business activities according to the classification of economic activities CZ-NACE in the examined aggregate create wholesale and retail (22\%). Building industry and industry are represented within the research identically with $13 \%$, within the region there are about 21000 , or 19000 as the case may be, and so they occupy the second and third positions from the point of view of CZ-NACE. Business activities according to CZ-NACE such as section A - agriculture, forestry and fishing, section B - mining and extraction and section I - accommodation, catering and restaurants, were eliminated from the research because of their different perception and management of company processes - these are completely specific groups. There was chosen a research sample from the basic aggregate with the method of improbability of random choice because of difficult conditions for data collection.

The research sample consists of 187 small and mediumsized enterprises of South Bohemia region. Composition of the research sample according to size (number of employees) and activity is indicated in "tab. II" and III .
TABLE II. Composition of the research sample of small and mediumsized enterprises according to number of employees.

\begin{tabular}{|c|c|c|}
\hline Number of employees & \multicolumn{2}{|l|}{ Number of enterprises } \\
\hline $\mathbf{0}-\mathbf{9}$ & 20 & $11 \%$ \\
\hline $\mathbf{1 0}-\mathbf{2 4}$ & 70 & $37 \%$ \\
\hline $\mathbf{2 5}-\mathbf{4 9}$ & 36 & $19 \%$ \\
\hline $\mathbf{5 0}-\mathbf{2 4 9}$ & 61 & $33 \%$ \\
\hline
\end{tabular}

TABLE III. Composition of the research sample of small and mediumsized enterprises according to business activity.

\begin{tabular}{|c|c|c|}
\hline Activity & \multicolumn{2}{|c|}{ Number of enterprises } \\
\hline Building industry & 51 & $27 \%$ \\
\hline Engineering & 57 & $30 \%$ \\
\hline Wood production & 22 & $12 \%$ \\
\hline Food production & 11 & $6 \%$ \\
\hline Commerce & 22 & $12 \%$ \\
\hline Services and Transport & 24 & $13 \%$ \\
\hline
\end{tabular}

\section{RESULTS}

Differences concerning strategies and their formulation in individual categories of examined small and medium-sized enterprises are indicated in "Tab. IV and V". From the point of view of categories according to number of employees, as in the "Tab. V", it is evident, that the majority (always more than $60 \%$ ) of enterprises has formulated strategy.

In the medium-sized enterprises (with more than 50 employees) the frequency is about $87 \%$. It is surprising that $72 \%$ of micro-enterprises (up to 9 employees) also have formulated strategy. From the point of view of written formulation of the examined strategy the number of enterprises is lower, due to the fact that the number logically grows with the company size. Micro-enterprises have written formulated strategy only in $9 \%$ of cases, on the contrary medium-sized enterprises in $63 \%$ of cases, at the same time enterprises with more than 150 employees have written formulated strategy in $83 \%$ of cases.

TABLE IV. Frequencies of formulated strategies of examined small and medium-sized enterprises according to the number of employees.

\begin{tabular}{|c|c|c|c|c|c|}
\hline \multirow{2}{*}{$\begin{array}{c}\text { Number } \\
\text { of } \\
\text { employees }\end{array}$} & \multirow{2}{*}{$\begin{array}{c}\text { Number of } \\
\text { enterprises }\end{array}$} & \multicolumn{2}{|c|}{ Formulated strategy } & \multicolumn{2}{|c|}{$\begin{array}{c}\text { Written formulated } \\
\text { strategy }\end{array}$} \\
\cline { 3 - 6 } & $\boldsymbol{y e s}$ & $\boldsymbol{n o}$ & $\boldsymbol{y e s}$ & no \\
\hline $\mathbf{0}-\mathbf{9}$ & $\mathbf{2 0}$ & $72 \%$ & $\mathbf{2 8 \%}$ & $9 \%$ & $81 \%$ \\
\hline $\mathbf{1 0}-\mathbf{2 4}$ & 70 & $61 \%$ & $39 \%$ & $30 \%$ & $70 \%$ \\
\hline $\mathbf{2 5}-\mathbf{4 9}$ & 36 & $69 \%$ & $31 \%$ & $61 \%$ & $39 \%$ \\
\hline $\mathbf{5 0}-\mathbf{2 4 9}$ & 61 & $87 \%$ & $13 \%$ & $63 \%$ & $37 \%$ \\
\hline
\end{tabular}

The formulation of strategy from the point of view of categories according to business activity is shown in the "Tab. VI”. It is similar for all enterprises that always at least $60 \%$ of 
them have formulated strategy. Most of the enterprises with formulated strategy are in the service sector (81\%), and also with the written strategy (59\%). The enterprises in commerce show a little bit lower frequency, $76 \%$ of them have includes the growth of revenues and also decrease of costs.

TABLE VI. Frequency of followed strategies in examined SMEs according to the number of employees.

formulated strategy and $44 \%$ strategy in written form. Generally said enterprises in the field of production show the frequency about $74 \%$ in relation to the formulated strategy and $40 \%$ in relation to the written formulated strategy.

Strategies are most often created by enterprises which are concentrated on engineering production (81\%, 49\% written strategies). On the other hand

\begin{tabular}{|c|c|c|c|c|c|c|}
\hline $\begin{array}{l}\text { Number of } \\
\text { employees }\end{array}$ & $\begin{array}{l}\text { Number of } \\
\text { enterprises }\end{array}$ & $\begin{array}{l}\text { Not } \\
\text { specified }\end{array}$ & Quality & Stabilization & Development & Profit \\
\hline $\mathbf{0 - 9}$ & 20 & $36 \%$ & $36 \%$ & $14 \%$ & $9 \%$ & $5 \%$ \\
\hline $\mathbf{1 0}-\mathbf{2 4}$ & 70 & $40 \%$ & $34 \%$ & $14 \%$ & $9 \%$ & $3 \%$ \\
\hline $\mathbf{2 5}-\mathbf{4 9}$ & 36 & $36 \%$ & $28 \%$ & $19 \%$ & $11 \%$ & $6 \%$ \\
\hline $\mathbf{5 0}-\mathbf{2 4 9}$ & 61 & $16 \%$ & $58 \%$ & $16 \%$ & $5 \%$ & $5 \%$ \\
\hline
\end{tabular}
only $57 \%$ of enterprises which are focused on wooden production create strategies and only $14 \%$ of them have a written version. Also the construction enterprises focus on strategies less - only $63 \%$ of them prepare their strategies and only $39 \%$ out of the examined enterprises have a written form.

TABLE V. Frequency of examined SMEs with a strategy according to business area.

\begin{tabular}{|l|c|c|c|c|c|}
\hline \multirow{2}{*}{ Business area } & \multirow{2}{*}{$\begin{array}{l}\text { Number of } \\
\text { enterprises }\end{array}$} & \multicolumn{2}{|c|}{ Prepared strategy } & \multicolumn{2}{c|}{ Written version } \\
\cline { 3 - 6 } & & yes & no & yes & no \\
\hline Construction & 51 & $63 \%$ & $37 \%$ & $39 \%$ & $61 \%$ \\
\hline $\begin{array}{l}\text { Engineering } \\
\text { production }\end{array}$ & 57 & $81 \%$ & $19 \%$ & $49 \%$ & $51 \%$ \\
\hline $\begin{array}{l}\text { Wooden } \\
\text { production }\end{array}$ & 22 & $57 \%$ & $43 \%$ & $14 \%$ & $86 \%$ \\
\hline Food production & 11 & $75 \%$ & $25 \%$ & $37 \%$ & $63 \%$ \\
\hline Trade & 22 & $76 \%$ & $24 \%$ & $44 \%$ & $56 \%$ \\
\hline $\begin{array}{l}\text { Services and } \\
\text { Transport }\end{array}$ & 24 & $81 \%$ & $19 \%$ & $59 \%$ & $41 \%$ \\
\hline
\end{tabular}

Out of 187 examined enterprises 31\% of them didn't indicate their strategy type. The rest of the examined SMEs are focused on strategy of survival. Four categories were determined:

- $\quad$ "Quality" (41\% of examined enterprises) - enterprises focus on quality in all aspects of bussines, on business ethics, they aim to have a good name, they are oriented on customers and make all the effort to satisfy them, these enterprises are working towards higher flexibility and reliability in everyday praxis and also try to make their employees satisfied

- "Stabilization" (16\% of examined enterprises) enterprises focus on stabilization within the market but also on consolidation of its internal environment, for example keeping the same number of employees

- "Development" (8\% of examined enterprises) enterprises focus on development of the enterprise in many areas - extension of production or provided services, market share and innovations

- $\quad$ "Profit" (4\% of examined enterprises) - enterprises focus on a long-standing growth of profit, this
Table VI shows the differences between strategies of SMEs from different categories. It can be seen that the strategy structure of examined enterprises is similar, similarity can also be seen in the terms of order of relative frequencies. Categories differ in terms of followed strategies. Dominant strategy is "Quality" followed by 30\% of small enterprises (less than 50 employees), on the other hand more than half (58\%) of the enterprises with more than 50 employees follow this strategy. The second most common strategy is "Stabliziation" - around 20\% of enterprises choose this strategy to reach their goals. "Development" strategy is followed by $10 \%$ of enterprises but enterprises with more than 150 employees don't implement this strategy at all. The last strategy "Profit" is followed by $5 \%$ of enterprises.

A Table VII show a similar analysis of SMEs presenting the results according to a business area. The structure of the implemented strategies is similar as above where the categories were created according to the number of employees, but some differences can be seen in the sequence of relative frequencies. Enterprises working in construction usually follow "Quality" and "Stabilization" strategies, 9\% of enterprises follow "Profit" strategy and only 7\% follow "Development". "Quality“ was the most followed strategy by manufacturing enterprises, even more dominantly, as it was chosen by $40 \%$ businesses as the device to reach their goals. $17 \%$ manufacturing enterprises in total follow "stabilization strategy", about half of them follow strategy focused on "development", and just $2 \%$ of the companies follow the strategy "profit".

Engineering production companies follow dominantly strategy of "quality", wood processing and food industry companies follow strategy of "stabilization" similarly. Most trading companies (Commerce, 52\%) follow strategy of "quality", 20\% of companies are focused on strategy of "stabilization", just 4\% strive for fulfillment of "development strategy“. No trading company sets profit strategy as its goal. Service companies follow mostly quality strategy (57\%), the second most frequent strategy was "development”. Just few service companies follow "profit"(5\%) or "stabilization"(3\%) strategy. 
TABLE VII. Frequency of SME observed strategies according to the business activity.

\begin{tabular}{|l|c|c|c|c|c|c|}
\hline $\begin{array}{l}\text { Business } \\
\text { activity }\end{array}$ & $\begin{array}{c}\text { Number of } \\
\text { enterprises }\end{array}$ & $\begin{array}{c}\text { Not } \\
\text { specified }\end{array}$ & Quality & Stabilization & Development & Profit \\
\hline $\begin{array}{l}\text { Building } \\
\text { industry }\end{array}$ & 51 & $38 \%$ & $24 \%$ & $23 \%$ & $7 \%$ & $8 \%$ \\
\hline $\begin{array}{l}\text { Production } \\
\text { engineering }\end{array}$ & 57 & $36 \%$ & $41 \%$ & $10 \%$ & $11 \%$ & $2 \%$ \\
\hline $\begin{array}{l}\text { Wood } \\
\text { processing } \\
\text { industry }\end{array}$ & 22 & $19 \%$ & $38 \%$ & $33 \%$ & $5 \%$ & $5 \%$ \\
\hline $\begin{array}{l}\text { Food } \\
\text { industry }\end{array}$ & 11 & $37 \%$ & $38 \%$ & $25 \%$ & $0 \%$ & $0 \%$ \\
\hline $\begin{array}{l}\text { Commerce } \\
\text { Service } \\
\text { trade and } \\
\text { transport }\end{array}$ & 22 & $24 \%$ & $52 \%$ & $20 \%$ & $4 \%$ & $0 \%$ \\
\hline
\end{tabular}

TABLE VIII. Correlation coefficient of MSE strategy according to the

Causal effects of strategy choice among the observed small and medium enterprises according to the number of employees' category and the type of business activity were tested using statistical method of Kruskal-Wallis test. First, the relation between strategy choice and number of employees was tested. Based on the analyzed data we were able to confirm with 95\% probability the null hypothesis that says there is no relation between tested variables $(\mathrm{H}=$ 6,675946; df = 4; p-value = 0,1540).

Further, the relation between strategy choice and category of business activity was tested. Based on analyzed data we were able to reject with $95 \%$ probability the null hypothesis in

\section{RESUlT}

Majority of the examined small and medium

\begin{tabular}{|l|r|r|r|r|r|r|}
\hline & $\begin{array}{l}\text { Building } \\
\text { Industry }\end{array}$ & $\begin{array}{l}\text { Production } \\
\text { Engineering }\end{array}$ & $\begin{array}{l}\text { Wood } \\
\text { Processing } \\
\text { Industry }\end{array}$ & $\begin{array}{l}\text { Food } \\
\text { Industry }\end{array}$ & Commerce & $\begin{array}{l}\text { Service } \\
\text { and } \\
\text { Transport }\end{array}$ \\
\hline $\begin{array}{l}\text { Building } \\
\text { Industry }\end{array}$ & & 0,438736 & 0,741967 & $-0,102815$ & 0,808746 & 0,518120 \\
\hline $\begin{array}{l}\text { Production } \\
\text { Engineering }\end{array}$ & 0,438736 & & 0,294688 & 0,022168 & 0,000000 & 0,319173 \\
\hline $\begin{array}{l}\text { Wood } \\
\text { Processing } \\
\text { Industry }\end{array}$ & 0,741967 & 0,294688 & & $-0,146748$ & 0,543214 & 0,683588 \\
\hline $\begin{array}{l}\text { Food } \\
\text { Industry }\end{array}$ & $-0,102815$ & 0,022168 & $-0,146748$ & & 0,000000 & 0,345930 \\
\hline Commerce & 0,808746 & 0,000000 & 0,543214 & 0,000000 & & 0,147087 \\
\hline $\begin{array}{l}\text { Service and } \\
\text { Transport }\end{array}$ & 0,518120 & 0,319173 & 0,683588 & 0,345930 & 0,147087 & \\
\hline
\end{tabular}

favor of the alternative hypothesis that say that there is the relation between examined variables $(\mathrm{H}=7,849167$; $\mathrm{df}=3$; $\mathrm{p}$ value $=0,0492)$. This relation was tested using correlation coefficient r. Interdependence of strategy choice and particular business activity is evident in "Tab. VIII". The strongest correlation (80\%) was detected by strategy choice of product engineering and trading companies. Strong correlation (74\%) was also found by determining strategy of building companies and wood processing companies. $68 \%$ correlation is visible at strategy choice of wood processing and service (transport included) companies. Last significant correlation, higher than $50 \%$, were discovered by wood processing and trading companies; building and service companies (transport included). On the other hand no correlation was detected by determining strategy of production engineering and trading companies, food industry and trading companies. business activity. enterprises has a formulated strategy, however, in most cases only the enterprises with more than 25 employees also have a written version. From the business activity point of view, a distinctly lower frequency of formulated strategy at wood processing companies is obvious. Strategy is formulated and put down also in words mostly often by trading and service (transport included) enterprises. Based on the tested data the most frequently followed strategy is quality and stabilization, regardless of employees number category or business activity.
[1] Řehoř, P., 2007. Analysis of the labour market due to the achieved level of entrepreneurial activities in the regions of the Czech Republic. Conference: 5th Scientific International Conference on Hradec Economical Days 2007, Location: Hradec Kralove, CZECH REPUBLIC Date: FEB 06-07, 2007. Pages: 248-253. ISBN 978-807041-824-6.

[2] Srpová, J. a V. Řehoř, 2010. Základy podnikání : teoretické poznatky, přklady a zkušenosti českých podnikatelì. 1. vyd. Praha: Grada, 427 s. ISBN 978-80-247-3339-5.
[3] Team of autors: 2012. Manažment malých a stredných podnikov. 1.vyd. Nitra: Gramond, 331 s. ISBN 978-80-89148-85-1

[4] Keřkovský, M. a O. Vykypěl, 2006. Strategické rízení: teorie pro praxi. 2. vyd. Praha: H. Beck, 206 s. ISBN 80-7179-453-8.

[5] Sedláčková, H. a K. Buchta, 2006. Strategická analýza. Praha: C. H. Beck, 121 s. ISBN 8071793671.

[6] Dedouchová, M., 2001. Strategie podniku. 1. vyd. Praha: C.H. Beck, 256 s. ISBN 80-7179-603-4.

[7] Kotler, P. a K. L. Keller, 2012. Marketing management. 14 vyd. New Jersey: Prentice Hall, 816 s. ISBN 978-0-13-210292-6.

\section{Creative Commons Attribution License 4.0 (Attribution 4.0 International, CC BY 4.0)}

This article is published under the terms of the Creative Commons Attribution License 4.0

https://creativecommons.org/licenses/by/4.0/deed.en_US 